\title{
Technology Commercialization Office Role in Technology University A Case in A Technology University in Indonesia
}

\author{
Didin Kristinawati \\ School of Business and Management, Bandung Institute of \\ Technology. West Java, Indonesia \\ didinwati@sbm-itb.ac.id
}

\author{
Atik Aprianingsih \\ School of Business and Mangement, Bandung Institute of \\ Technology. West Java, Indonesia. \\ atik.apri@sbm-itb.ac.id
}

\begin{abstract}
University, with its mixed role of teaching and research, is believed to be the source of innovation stock. The study shall explore the commercialization technology in the oldest technical university in Indonesia. It can be assumed that such university relatively has productivity in creating sciences and technology inventions.

The step of commercializing university invention in the MIT conventional model is related with the role of TCO. Therefore, the research will specifically address to what extent the role of Technology Commercialization Office (TCO) in Indonesian technology university has been applied. Case study was used in this study as a research method to observe the role of TCO in higher education. The data collections were mainly conducted through interviews with key persons in university TCO also with academic staff and students. The result shows the university has already established technology commercialization. The organization structure of TCO is directly under university vice president of research and innovation which reflects the urgency of TCO to foster innovation commercialization. The socialization of TCO program is frequently implemented, however the database of property right is poor. In addition, due to unclear engagement with the faculty member in attracting the willingness of researcher to submit the invention through TCO, the engagement of faculty member with TCO needs to be studied in the future research
\end{abstract}

Keywords- Technology Commercialization office (TCO); University Technology Transfer; Role of TCO; Indonesian Technology Institute

\section{INTRODUCTION}

University is the source and stock of science and technology expertise. Traditionally, the role of university is acknowledged as the education facilitator and basic research conductor[1]. In recent years, the role is expanded with the needs of university to transfer the technology. Technology transfer is defined as the movement of knowledge and discoveries to the general public[2]. Statistically, only 10 from 100 research ideas are continued into research project.. From that number, only 2 whose value of commercialization are potential, ended with only 1 of those 2 being successfully commercialized[3]. The facts above lead to the curiosity of the research commercialization in Indonesian university. This study shall explore the commercialization technology in the oldest technical university in Indonesia, which t relatively can be assumed to have productivity in creating sciences and technology inventions. Additionally, the university sets direction towards entrepreneurial university[4] which means that it will employ more efforts in the technology commercialization. .

Burton R.Clark[5] argued that an entrepreneurial university actively seeks innovation and is not afraid to maximize their potential for commercializing their ideas and creating value in society. One of Clark arguments for entrepreneur university is the university is capable of making use the diversity in the funding sources. They should be able to not only using government third stream funding but also attempting to discover variety of sources and an integrated entrepreneurial culture, defined in terms of common commitment to change. According to Ropke[6], an entrepreneurial university can mean the creation of enterprise culture, particularly as one that is open to change and to the search for, and exploitation of, opportunities of innovation and development[7]. Entrepreneur university ensures that they are building its sustainability and become desirable partner for business and government sector. The members of the university (faculty, students, employees) are turning themselves somehow into entrepreneurs. Etzkowitz[8] puts five propositions concerning the entrepreneurial university concept, that such institutions focus upon capitalization of knowledge and on managing interdependence with industry and government. Technology commercialization studied in the research is aligned with Clark arguments that an entrepreneurial university actively seeks to innovate and is not afraid to maximize their potential for commercializing their ideas and creating value in society.

The dominant paradigm of technology commercialization is MIT model [9] which can be divided into eight activities : Research, Invention disclosure, Assessment, Patenting, Identifying potential licensees, Negotiation, Licensing, Revenue \& commercialization. Started from second phase of Invention Disclosure, the role of Technology Commercialization Office (TCO) is required. The second activities of Invention Disclosure explains that an inventor's first step in the commercialization process is to submit an invention disclosure. This is the beginning of a relationship between a researcher and university technology 
commercialization office (or technology transfer office/TCO). By submitting an invention disclosure, the inventor enables TCO to offer assistance and support throughout the commercialization process if the university asserts its interest in the technology. The next step of commercializing technology in the conventional model is to relate it with the role of TCO. Therefore, the research will specifically address the role of Technology Commercialization Office (TCO) in Indonesian technology university as the central research question.

\section{THEORETICAL OVERVIEW}

\section{A. Technology Commercialization Model}

Firstly, the term of technology commercialization and technology transfer needs to be clarified. From the literature, technology transfer is defined as movement of knowledge and discoveries to the general public[2]. Another definition says that technology transfer is a term used to describe a formal transfer of rights to use and commercialize new discoveries and innovations resulting from scientific research to another party. Universities typically transfer technology through protecting (using patents and copyrights), then licensing new innovations.

In addition to that, technology commercialization is defined as the activity of making a business model to increase profits by providing value to subject customers through the development of products or services using special technologies. Here, specialized technology means combined technology integrating the already commercialized individual technologies, creative technology developed in house by corporations, and the technology licensed by other corporations or research organizations.

From the definitions, the study assumes that the term technology transfer and technology commercialization can be used interchangeably. However, the term of technology commercialization will be used in the study to specify the invention in university that has been successfully commercialized in the forms of patent, license, or spin-off company.

The dominant paradigm of technology commercialization is MIT model [9] which can be divided into eight activities of: Research, Invention disclosure, Assessment, Patenting, Identifying potential licensees, Negotiation, Licensing, Revenue, andCommercialization

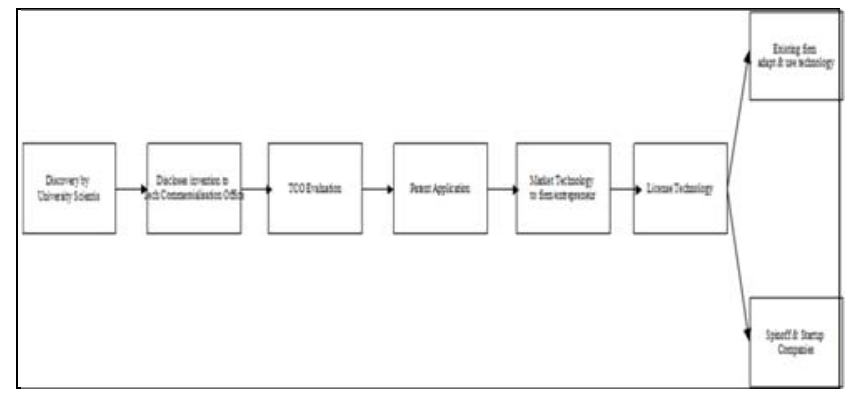

Figure 1. MIT Model of University Technology Transfer
In the first activities of Research, the question to be addressed is who owns the invention in the university? Inventor-ship is not the same as ownership. Therefore, how will the university deal with the problem of inventor-ship and ownership. Can a student contribute to an invention? What if the invention was created with someone from another institution or company? The second activities involves Invention Disclosure that explains inventor's first step in the commercialization process, that is to submit an invention disclosure. This is the beginning of a relationship between a researcher and university technology commercialization office (or technology transfer office/TCO). By submitting an invention disclosure, the inventor enables the TCO to offer assistance and support throughout the commercialization process if the university asserts its interest in the technology.

The third activity of assessment occurs after the TCO receives invention disclosure. Then, based on the nature of its science, each invention is assigned to a licensing specialist who specializes in the field. The fourth activity of patenting requires a thorough study of legal protection. The fifth activity is identifying potential market (licenses) to address whether the university collaborates with entrepreneurs, angel investors, technology incubators, venture capital firms, large enterprises, and others within the ecosystem to commercialize technologies developed by the university researchers. The sixth activity is negotiation. It is TCO diligence in negotiating a deal that is a win-win for all parties involved. The seventh activity is Licensing to grant the rights to use the university invention.

\section{B. The Role of Technology Commercialization Office (TCO)}

The role of TCO is tabulated below, based on the works of some authors:

Table 1. The role of TCO

\begin{tabular}{|l|l|}
\hline \multicolumn{1}{|c|}{ Researcher } & \multicolumn{1}{|c|}{ Role of TCO } \\
\hline $\begin{array}{l}\text { Bercovitz, } \\
\text { Feldman, Feller, } \\
\text { and Burton }\end{array}$ [10] & $\begin{array}{l}\text { Technology transfer activities (eliciting and } \\
\text { processing invention disclosures, licensing } \\
\text { university-created knowledge, seeking additional } \\
\text { sponsorship of R\&D projects or a combination of } \\
\text { these three) are shaped by the resources, reporting } \\
\text { relationships, autonomy, and/or incentives of } \\
\text { TCOs. }\end{array}$ \\
\hline $\begin{array}{l}\text { Friedman and } \\
\text { Silberman [11] }\end{array}$ & $\begin{array}{l}\text { Almost all universities have established TCOs to } \\
\text { foster interaction with industry and } \\
\text { commercialization of research. After an invention } \\
\text { is conveyed to the TCO, it is responsible for } \\
\text { patenting it. }\end{array}$ \\
\hline $\begin{array}{l}\text { O'Shea, Allen, } \\
\text { Chevalier, and } \\
\text { Roche [12] }\end{array}$ & $\begin{array}{l}\text { The TCO plays a key role in engendering } \\
\text { academic entrepreneurship by engineering } \\
\text { synergistic networks between academics and } \\
\text { venture capitalists, advisors, and managers who } \\
\text { provide the human and financial resources } \\
\text { necessary to start a company; and by providing } \\
\text { company formation expertise (many TCO } \\
\text { personnel have experiences in evaluating markets, }\end{array}$ \\
\hline
\end{tabular}




\begin{tabular}{|l|l|}
\hline \multicolumn{1}{|c|}{ Researcher } & \multicolumn{1}{c|}{ Role of TCO } \\
\hline & $\begin{array}{l}\text { writing business plans, raising venture capital, } \\
\text { obtaining space and equipment, etc.) }\end{array}$ \\
\hline $\begin{array}{l}\text { Siegel, } \\
\text { Waldman, } \\
\text { Atwater, and }\end{array}$ Link] & $\begin{array}{l}\text { The role of the TCO is to facilitate commercial } \\
\text { knowledge transfers through the licensing to } \\
\text { industry for their inventions or other forms of } \\
\text { intellectual property resulting from university } \\
\text { research. The TCO must understand the field and } \\
\text { must evaluate the direction of where its technology } \\
\text { is moving in order to decide whether or not a } \\
\text { patent should be filed on the discovery. }\end{array}$ \\
\hline
\end{tabular}

\section{RESEARCH METHOD}

Case study was used in this study as a research method to observe the role of TCO in higher education. The case study using multiple sources of data is expected to bring out details from participants viewpoint [14]. The case of Bandung Institute of Technology for the study is appropriate since it is the oldest technical university in Indonesia. Therefore, it can be assumed that the university relatively has productivity in creating sciences and technology inventions. Moreover, currently the university sets its direction towards entrepreneurial university[4] which means that the university will employ more efforts in the technology commercialization.

The data collections were mainly conducted through interviews with key persons in TCO of the university also with the academic staff and students. Furthermore, the data were also collected from the firm' archives, official websites, reports, and related documents. Descriptive analysis and pattern matching technique[14] were also used to analyze the collected data. The pattern matching was performed through data collection analysis using the provided theoretical framework by comparing two patterns in order to determine whether the findings match the previous constructed pattern in the theoretical review.

\section{TEChNOLOGY COMMERCIALIZATION OFFICE IN THE UNIVERSITY NAMELY TCO}

Technology Commercialization Office in the university is known as Innovation Development and Entrepreneur (IDE). The organization structure of TCO is under university vice president of research and innovation. Its missions are: (i) facilitating the university development of innovation through business, community, government, industry partnerships; (2) guiding the development and changes of community through innovation and entrepreneurship development activity, which bring direct and significant impact on improving people's welfare. The role divisions of TCO can be divided into four :

Table 2. The Divisions Role of TCO

\begin{tabular}{|l|l|}
\hline A.Division Property Right & C.Division Industry Incubator \\
a. The university Innovation data & a. Developing Start-up companies \\
collection & b. Promoting the university \\
b. Property RightSocialization c & Innovation result \\
\hline
\end{tabular}

\begin{tabular}{|c|c|}
\hline $\begin{array}{l}\text { and Consultation } \\
\text { c. Property Right Workshop } \\
\text { d. License Arrangement } \\
\text { e. Developing Property Right Rule } \\
\text { for the university }\end{array}$ & $\begin{array}{l}\text { c. Business Planning } \\
\text { d. Partnership }\end{array}$ \\
\hline $\begin{array}{l}\text { B. Entrepreneurship Division } \\
\text { a. Education and Networking } \\
\text { b. Workshop, Seminar, Exhibition } \\
\text { c. SME Collaboration } \\
\text { d.Business Coaching and } \\
\text { Consultancy } \\
\text { e. Post-graduate fellowship }\end{array}$ & $\begin{array}{l}\text { D.Techno-park Division } \\
\text { a. Identify industry potential } \\
\text { b.Developing network and industry } \\
\text { ecosystem } \\
\text { c. Developing Techno-park } \\
\text { d. Campus Innovation Gallery }\end{array}$ \\
\hline
\end{tabular}

The current programs of the university TCO are: (i) Development of business planning; (ii) Market research for product innovation ; (iii) Property Right Management, also for industry design right; (iv). Development of organization management and business ; (v) Development partnership industry ; (vi) Promotion and Publication of product innovation.

The potential innovations identified by TCO are listed below:

Table 3. The Potential Innovation at the university

\begin{tabular}{|c|c|}
\hline Field of Innovation & Potential Innovation \\
\hline Environment energy & $\begin{array}{l}\text { Power Flow sea } \\
\text { Increased Calories Coal } \\
\text { Bio-gas reactor } \\
\text { Gasification technology } \\
\text { Low Head Run of River Hydro Power Turbine } \\
\text { Solar Cell } \\
\text { Pre-paid Meter KWH By Using Credit } \\
\text { KWH Meter } \\
\text { Power Plant Solid Waste } \\
\text { Windmill Road Toll } \\
\text { Windmills Billboard Lights } \\
\text { Windmills For BTS Tower } \\
\text { Wind turbines }\end{array}$ \\
\hline $\begin{array}{l}\text { Information and } \\
\text { Communication } \\
\text { Technology }\end{array}$ & $\begin{array}{l}\text { Application Simulator Livestock Dairy Farm } \\
\text { 3D Scanner and Render farm } \\
\text { Base-band and MAC Chip-set } \\
\text { Information Technology Risk Analysis Method } \\
\text { Based on Asset Threat Scenario Dependencies } \\
\text { Different } \\
\text { Multi-system BTS antennas (3G / UMTS / LTE } \\
\text { / mWiMAX) } \\
\text { Operator Training Simulator } \\
\text { Augmented Reality Tsunami } \\
\text { V520 Smart Terminal } \\
\text { Virtual Class Box } \\
\text { Multimedia Applications Safety }\end{array}$ \\
\hline Biotechnology & $\begin{array}{l}\text { GIH dsRNA (double Stranded RNA GIH) for } \\
\text { Aquaculture Parent / Tiger Shrimp Broodstock } \\
\text { A-Amylase enzymes (Bio Catalyst Textile } \\
\text { Industry) } \\
\text { Tissue Culture Aglonema }\end{array}$ \\
\hline Manufacture & $\begin{array}{l}\text { Products Control and Instrumentation } \\
\text { Reverse engineering and Tool Making }\end{array}$ \\
\hline Health \& Medicine & $\begin{array}{l}\text { Bulbus Extract Garlic (Allium sativum Lin) and } \\
\text { rhizome Turmeric (Curcuma longa Lin.) As } \\
\text { anti-diabetic and Antidislipidemia } \\
\text { Development of Therapeutic Proteins } \\
\text { Recombinant Interferon } \alpha 2 b \\
\text { Through Streptokinase Therapeutic Protein } \\
\text { Protein Engineering } \\
\text { ECG "Moyo" } \\
\text { Clamps Fasteners On the Tools For Connecting } \\
\text { External Fixation Broken Bones } \\
\text { Woltru (Aid Road) }\end{array}$ \\
\hline
\end{tabular}




\begin{tabular}{|l|l|}
\hline Field of Innovation & Potential Innovation \\
\hline & Instrument Engineering Dentistry Equipment \\
\hline Creative Industry & Substitute Material Fiberglass Fiberboo Material \\
& Rattan Furniture Design with Random Anyam \\
& Engineering Materials Water Hyacinth \\
& Game Shooting Simulator \\
& Game Tank Simulator \\
& Indonesia Home Theater Design \\
& The load on the tool Vibration Absorbers \\
& Backpack \\
& Simulation games Safety \\
& Heater for Fast Food \\
\hline
\end{tabular}

\section{DISCUSSION AND CONCLUSION}

Considering the crucial role of TCO in university technology commercialization process, the existence of TCO is mandatory. The organization structure of TCO is directly under the university vice president of research and innovation, which reflects the urgency of TCO as university TCO to foster innovation commercialization. Innovation Development and Entrepreneur are considered as TCO for the university. Its role covers the role of TCO in MIT model of university technology commercialization. It can be seen in the organization division of TCO which comprises of Property Right, Industry Incubator, Entrepreneurship, and Techno-park. The role of each division may cover information dissemination, publication, education, patenting, networking industry, incubator, and spin-off which in compliance with the idea of TCO by Friedman and Silberman[11].

The role of division is vary widely from socialization to company start-up development that can be listed as follows: the university Innovation data collection, Property Right, Socialization and Consultation, Property Right Workshop, License Arrangement, Developing Property Right Rule for the university, Developing Start-up companies, Promoting university Innovation result, Business Planning, Partnership, Education and Networking, Workshop, Seminar, Exhibition, SME Collaboration, Business Coaching and Consultancy, Post-graduate fellowship, Identify industry potential, Developing network and industry ecosystem, Developing Techno-park, and Campus Innovation Gallery. However, the question is whether all the roles listed have been implemented or not. From the set of roles mentioned before, the frequent implementations are in socialization and consultation, workshop seminar and exhibition, identification of potential innovation, and incubator for tenant. The implementation of property right is unclear, for example the poor database of the university property right. Additionally, the engagement with the faculty member to attract researcher's willingness to submit the invention through TCO is under question. Some of faculty members patented their invention independently. This raises a concern regarding the function of university resources during the research and invention. The identification of potential innovation shows that Energy, ICT, Medicine, and Creative Industry dominate the innovation. It is in accordance with the crucial world issue of energy depletion, era of ICT, and the booming creative industry especially in Bandung.
From the explanation above, it can be concluded that the university has already established technology commercialization office namely TCO. The organization structure of TCO is directly under the university vice president of research and innovation, which reflects the urgency of TCO as university TCO to foster innovation commercialization. The socialization program of TCO is frequently implemented, however the database of the university property right is poor. In addition, the engagement with the faculty member to attract the willingness of researcher to submit the invention through TCO is under question. Therefore, for future research, or for the continuation of this research, the engagement of faculty member with TCO should be studied.

\section{Acknowledgment}

This research would not have been possible without the research grant from School of Business and Management, Bandung Institute of Technology.

\section{References}

[1] Todtling, Frans. "The Role of Universities in Innovation Systems and Regional Economies." Expert Meeting on The Future of Academic Research, Vienna 19-20 October 2006

[2] AUTM. "FAQs What is Technology Transfer", Association of University Technology Managers. http://www.autm.net/FAQs/2186.htm\#1 Accessed 30 March 2015

[3] Parker,K. Dan Mainelli,M. "Great Mistakes in Technology Commercialization.” Strategic Change, 2001, Vol.10 No.7,383-390

[4] Kadarsah. "Kadarsah Suryadi, Rektor ITB 2014-2019: ITB untuk Menjadi Entrepreneurial University." http://www.the university.ac.id/news/4600.xhtml. Published 15 Desember 2014. Accessed 30 January 2015

[5] Clark, B. R. "Creating entrepreneurial universities: Organisational pathways of transformation". Oxford: Elsevier, 1998

[6] Ropke, J. "The entrepreneurial university: Innovation, academic knowledge creation and regional development in a globalized economy." Working paper, 1998, Philipps-Universität Marburg

[7] Gibb, A. "Towards the entrepreneurial university: Entrepreneurship education as a lever for change." Policy Paper, 2005, Series 15

[8] Etzkowit Z, H ., A. Webster, C. Gebhardt, T. Cantisano, and R. Brance. "The future of the university: Evolution of ivory tower to entrepreneurial paradigm.” Research Policy, 2000, 29 (2): 313-30.

[9] Bradley, Samantha et al,.."Models and Methods of University Technology Transfer". Departement Economics Working Paper Series, 2015

[10] Bercovitz, J. E. L, M. P. Feldman, I. Feller, and R. M Burton. "Organizational Structure as a Determinant of Academic Patent and Licensing Behavior: An Exploratory Study of Duke, Johns Hopkins, and Pennsylvania State Universities." Journal of Technology Transfer, 2001, 26(1/2): 21-35

[11] Friedman, J. and Silberman, J. "University Technology Transfer: Do Incentives, Management, and Location Matter?", Journal of Technology Transfer, 2003, 28(1), pp. 17.

[12] O'Shea, Rory P. and Chevalier, Arnaud and Roche, Frank and Allen, Thomas J, "Entrepreneurial Orientation, Technology Transfer and Spinoff Performance of U.S. Universities", Research Policy, 2005, Vol. 34, Issue 7, p. 994-100 2005. Available at SSRN: http://ssrn.com/abstract=1498288

[13] Siegel, D.S., Waldman, D., and Link, A.N."Assessing the Impact of Organizational Practices on the Productivity of University Technology 
Transfer Offices: An Exploratory Study.” Research Policy, 2003, 32(1),

$27-48$.

[14] Yin, R. K. "Case study research: Design and methods." (4th Ed.).

Thousand Oaks, CA: Sage, 2009. 